Sains Malaysiana 49(6)(2020): 1421-1430

http://dx.doi.org/10.17576/jsm-2020-4906-20

\title{
Cytotoxic Effects of Organotin(IV) Dithiocarbamate Compounds with Different Functional Groups on Leukemic Cell Line, K-562
}

(Kesan Sitotoksik Sebatian Organotin (IV) Ditiokarbamat Berlainan Kumpulan Fungsian pada Sel Titisan Leukemia, K-562)

\author{
Asmah Hamid*, Mohd Azam Azmi, Nor Fadilah Rajab, Normah Awang \& Nurul Farhana Jufri
}

\begin{abstract}
Cancer is one of the main causes of mortality in the world. New compounds are currently being synthesized to overcome this disease. Organotin is getting more attention as anticancer agent due to its potent cytotoxic properties towards cancer cells. In this study, a series of newly synthesized organotin compounds known as dimethyltin(IV) (compound 1), dibutyltin(IV) (compound 2) and triphenyltin(IV)methylisoprophyldithiocarbamate (compound 3) have been assessed for their cytotoxic effect towards leukemic cell line K-562. MTT [3-(4,5-dimethylthiozol-2-yl)-2,5-diphenyltetrazolium bromide] assay was employed to determine the cytotoxic effect for each of the compounds at different time points and concentrations. Compound 2 and 3 exhibited potent cytotoxic effects towards K-562 cells with IC ${ }_{50}$ values less than $2 \mu \mathrm{M}$. Compound 3 was found as the most toxic towards $K-562$ cells based on the lowest $I C_{50}$ value for $72 \mathrm{~h}$ period of treatment at $0.25 \mu \mathrm{M}$. Morphological observation was conducted with $I_{50}$ values at 24,48 , and $72 \mathrm{~h}$. Results showed that the changes were first observed as early as $24 \mathrm{~h}$ and the most significant changes were observed after $72 \mathrm{~h}$ period of treatment with the characteristic of apoptosis such as cell shrinkage and membrane blebbing. In addition, necrosis characteristic such as cell lysis and swelling had also been observed. Organotin(IV) methylisopropyldithiocarbamate with different functional groups affect the cytotoxic properties towards leukemic cells $K-562$ and these compounds have potential to be developed as an anticancer agent through structural modification.
\end{abstract}

Keywords: Anticancer; cytotoxic; leukemia; MTT assay; organotin

\section{ABSTRAK}

Kanser merupakan penyebab utama kematian di seluruh dunia. Bagi menangani masalah ini, sebatian baru disintesis. Organotin semakin mendapat perhatian sebagai agen anti-kanser kerana mempunyai kesan antitoksik terhadap sel kanser. Dalam kajian ini, suatu siri sintesis bahan organotin dikenali sebagai dimetiltin (IV) (bahan 1), dibutiltin (bahan 2) dan trifeniltin (IV) metilisoprofilditiokarbamat (bahan 3) diuji untuk kesan sitotoksik terhadap sel leukemia K-562. Ujian MTT [3-(4,5-dimetiltiozol-2-il)-2,5-difenil-tetrazolium bromida] digunakan bagi menentukan kesan sitotoksik untuk setiap bahan pada tempoh masa dan kepekatan berbeza. Bahan 2 dan 3 menunjukkan kesan sitotoksik yang kuat terhadap sel K-562 dengan nilai IC ${ }_{50}$ kurang daripada $2 \mu M$. Bahan 3 menunjukkan kesan paling toksik terhadap sel K-562 berdasarkan nilai $I_{50}$ paling rendah selama 72 jam pada kepekatan $0.25 \mu M$. Pemerhatian morfologi pada nilai $I_{50}$ pada 24, 48 dan 72 jam menunjukkan perubahan morfologi berlaku seawal jam ke-24 dan perubahan signifikan pada 72 jam rawatan dengan ciri-ciri apoptosis seperti pengecutan sel dan pertumbuhan luar membran sel. Selain itu, sel nekrosis seperti sel lisis dan pembengkakan sel juga diperhatikan. Sebagai rumusan, bahan organotin (IV) metilisoprofilditiokarbamat dengan kumpulan fungsi berbeza memberikan kesan sitotoksik terhadap sel dan mempunyai potensi untuk dibangunkan sebagai agen anti-kanser melalui pengubahsuaian struktur.

Kata kunci: Anti-kanser; leukemia; organotin; sitotoksik; ujian MTT

\section{INTRODUCTION}

Studies on the chemical compounds provide a platform for the discovery of a new potential anticancer agents with diverse structures and biological activities. Research of the compounds that may have the potential as anticancer agents may require early screening tests for the appropriate dosage to inhibit the growth or kill the cancerous cells.
Before organotin compound was introduced and developed, cisplatin was the first synthetic metal-containing anticancer drug synthesized and acts as chemotherapy agent. However, cisplatin can lead to severe side effects to the patients and thus identification of safer metal-based compound has been widely being studied (Varela-Ramirez et al. 2011). Organotin is a compound that has tin (stannum) 
linked to the hydrocarbon. It has been widely used as pesticide, fungicide, bactericides, and plastic stabilizers (Varela-Ramirez et al. 2011). Many studies have been conducted on organotin compounds toward various tumour cell types and the results demonstrated that the organotin compounds are very effective as anti-tumour agents (Amir et al. 2014; Awang et al. 2011; Gleeson et al. 2008; Kamaludin et al. 2017). Understanding the organotin mechanism of action is part of the development of new anticancer drugs as the compounds have different toxicity, depending on the number and the nature of functional groups that attached to the tin atom.

Previously, several organotin compounds had been synthesized and tested as anticancer drugs and they also exhibited antibacterial and antimalarial activities (Awang et al. 2016, 2014; Baul et al. 2010; Hunakova et al. 2016; Tian et al. 2006). Interestingly, some of the compounds were found to have better anticancer activity than cisplatin (Gómez-Ruiz et al. 2008). Meanwhile, dithiocarbamate, a class of metal chelating compound has been widely used in agriculture, industry and medicine. In addition, it is used in chemotherapy, drug for alcohol prevention and as an antidote for metal toxicity (Hogarth 2012). It exhibits anti-tumor effects and has been proven to initiate apoptosis of tumour cell specific (Buac et al. 2012).

As these compounds have been proven to have potential to kill cancer cells, newly synthesized dimethyltin(IV), dibuthyltin(IV) and triphenyltin(IV) methylisoprophyldithiocarbamate (Figure 1) were investigated for its cytotoxicity effects against chronic mylogenous leukemic cell (K-562) that is resistance against apoptosis in this study. Thus, it's potential as anticancer agent could be identified to be developed as therapeutic agent in the future.

a)<smiles></smiles>

b)<smiles></smiles>

c)<smiles>CC(C)N(C)CS[Sn](c1ccccc1)(c1ccccc1)c1ccccc1</smiles> 
d)<smiles>COc1cccc2c1C(=O)c1c(O)c3c(c(O)c1C2=O)C[C@@](O)(C(=O)CO)C[C@@]3(C)O[C@H]1C[C@H](N)[C@H](O)[C@@H](C)O1</smiles>

e)

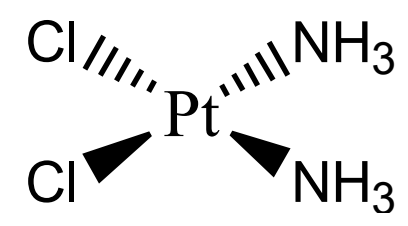

FIGURE 1. Chemical structure of a) dimethyltin(IV) methylisopropyldithiocarbamate (compound 1), b) dibutyltin(IV) methylisopropyldithiocarbamate (compound 2) and c) triphenyltin(IV) methylisopropyldithiocarbamate (compound 3). Cisplatin and doxorubicin were used as positive controls

\section{MATERIALS AND METHODS}

\section{PREPARATION OF STOCK COMPOUNDS}

All of the stock compounds were prepared at $100 \mathrm{mM}$. The compounds were weighted for $0.0534 \mathrm{~g}$ of compound $1,0.0635 \mathrm{~g}$ of compound 2 and $0.0597 \mathrm{~g}$ of compound 3 before they were fully dissolved in $1.2 \mathrm{~mL}$ dimethyl sulphoxide (DMSO) respectively. All of the stocks were stored at $4{ }^{\circ} \mathrm{C}$ and dilution was made with the addition of the media prior to the experiment.

\section{CULTURE OF K-562 CELL LINE}

K-562 cell line was purchased from American Type Culture Collection (ATCC CCL-243). These cells were cultured in Iscove's Modified Dulbecco's Medium (Sigma, United States) with supplementation of $10 \%$ Fetal Bovine Serum (FBS) (Sigma, United States) and $1 \%$ penicillin-streptomycin (Nacalai, Japan) to obtain complete growth media. The cells were incubated at 37 ${ }^{\circ} \mathrm{C}$ with $5 \% \mathrm{CO}_{2}$ incubator.

\section{MTT [3-(4,5-DIMETHYLTHIAZOL-2-YL)-2,5-DIPHENYLTIN- TETRAZOLIUM BROMIDE] ASSAY}

K-562 cell line was seeded in 96-well plate at $5 \times 10^{5}$ cells $/ \mathrm{mL}$ and treated with $2 \mu \mathrm{M}$ of compound 1,2 , and 3 for 24,48 , and $72 \mathrm{~h}$, respectively, in triplicate of three independent studies. The cells were treated with cisplatin and doxorubicin as positive controls while cells without treatment were used as negative control. After the incubation according to the time points, 20 $\mu \mathrm{L}$ of $0.5 \%$ MTT was added into each well. The cells were incubated for $4 \mathrm{~h}$ at $37^{\circ} \mathrm{C}$ with $5 \% \mathrm{CO}_{2}$. After $4 \mathrm{~h}$ incubation, $180 \mu \mathrm{L}$ of the supernatant was removed from each well and $180 \mu \mathrm{L}$ DMSO was added to each well. The color intensity was analyzed at $570 \mathrm{~nm}$ using ELISA microplate reader (Biochrom ASYS, United Kingdom). The values were analyzed in the form of graph by taking into account the average reading before $\mathrm{IC}_{50}$ value can be determined.

\section{CELL MORPHOLOGY}

K-562 cell line was cultured in a 6-well culture plates at $2 \times 10^{6}$ cells $/ \mathrm{mL}$ in triplicate. The concentration of the compounds used was based on the $\mathrm{IC}_{50}$ values obtained from MTT assay. The $\mathrm{IC}_{50}$ value for compounds 1,2 , and 3 were $0.1-0.8 \mu \mathrm{M}$, cisplatin was $40 \mu \mathrm{M}$ and doxorubicin was $0.5-32 \mu \mathrm{M}$. Cells without treatment were used as negative control. Cells were incubated according to each time points and the morphological changes in each different time points were observed under inverted microscope. 


\section{STATISTICAL ANALYSIS}

One-way ANOVA was used for statistical analysis. All data was presented as the mean \pm standard error of mean (S.E.M.). A $p$ value of $<0.05$ was considered statistically significant.

\section{RESULTS AND DISCUSSION}

The cytotoxic effects of dimethyl- (compound 1), dibuthyl- (compound 2), triphenyltin(IV) methylisoprophyldithiocarbamate (compound 3), cisplatin and doxorubicin on leukemic cells K-562 were investigated via MTT assay (Figures 2 and 3). At the highest concentration $(2 \mu \mathrm{M})$ of compound 1 , the average viability of the cells decreased from $100 \%$ viability in vehicle control to $90.33 \pm 2.84 \%$ after $24 \mathrm{~h}, 73.43 \pm$ $4.67 \%$ after $48 \mathrm{~h}$ and $92.53 \pm 2.32 \%$ after $72 \mathrm{~h}$. At the highest concentration of compound $2(2 \mu \mathrm{M})$, the average viability of cells was decreased from $100 \%$ viability in vehicle control to $54.52 \pm 1.80 \%$ after $24 \mathrm{~h}, 23.24$ $\pm 1.29 \%$ after $48 \mathrm{~h}$ and $23.78 \pm 3.73 \%$ after $72 \mathrm{~h}$. For compound 3 , the average viability cells were decreased from $100 \%$ viability in vehicle control to $43.12 \pm 1.32 \%$ after $24 \mathrm{~h}, 14.41 \pm 2.58 \%$ after $48 \mathrm{~h}$ and $12.08 \pm 1.11 \%$ after $72 \mathrm{~h}$. For cisplatin, the average viability of the treatment cells differs from $100 \%$ viability in vehicle control to $105.18 \pm 2.1 \%$ after $24 \mathrm{~h}, 91.23 \pm 5.49 \%$ after $48 \mathrm{~h}$ and $96.52 \pm 4.75 \%$ after $72 \mathrm{~h}$. Besides that, the average viability of cells treated with doxorubicin were decreased from $100 \%$ viability in vehicle control to 48.0 $\pm 2.09 \%$ after $24 \mathrm{~h}, 23.68 \pm 2.45 \%$ after $48 \mathrm{~h}$ and $17.32 \pm$ $1.13 \%$ after $72 \mathrm{~h}$.

MTT assay results demonstrated the cytotoxic effect of compound 1, 2, and 3 against K-562 cells after treatment with three different time points. The $\mathrm{IC}_{50}$ value after $24 \mathrm{~h}$ of treatment was $0.33 \mu \mathrm{M}$ for compound 3 but there was no $\mathrm{IC}_{50}$ detected for compound 1, 2 and cisplatin. At $48 \mathrm{~h}$, compound 3 showed that the $\mathrm{IC}_{50}$ value of $0.25 \mu \mathrm{M}$ and the $\mathrm{IC}_{50}$ value for compound 2 was 0.49 $\mu \mathrm{M}$. There were no $\mathrm{IC}_{50}$ value detected for compound 1 and cisplatin after $48 \mathrm{~h}$ of treatment. For $72 \mathrm{~h}$ of treatment, the $\mathrm{IC}_{50}$ value was $0.37 \mu \mathrm{M}$ for compound 3, $0.97 \mu \mathrm{M}$ for compound 2 and no $\mathrm{IC}_{50}$ value was detected for compound 1 and cisplatin. The $\mathrm{IC}_{50}$ value for doxorubicin in the treatment of 24,48 and $72 \mathrm{~h}$ respectively were $18.0,0.44$, and $0.34 \mu \mathrm{g} / \mathrm{mL}$.

a)

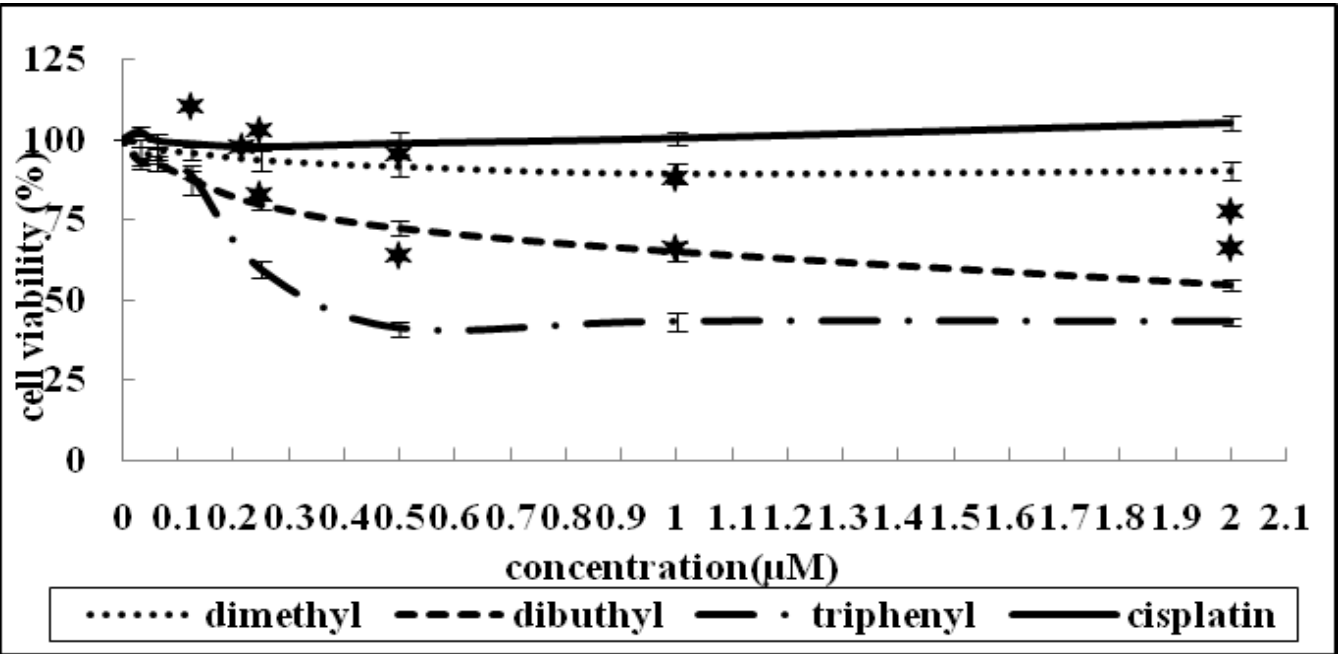

b)

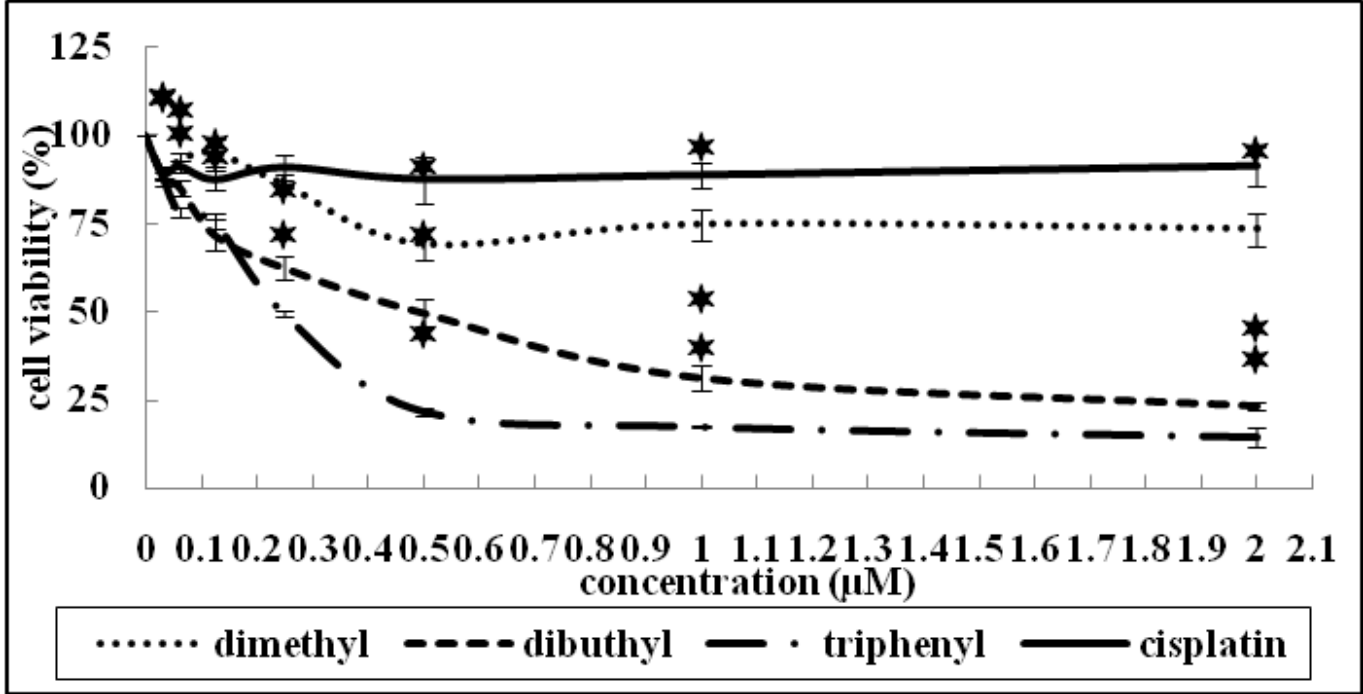


c)

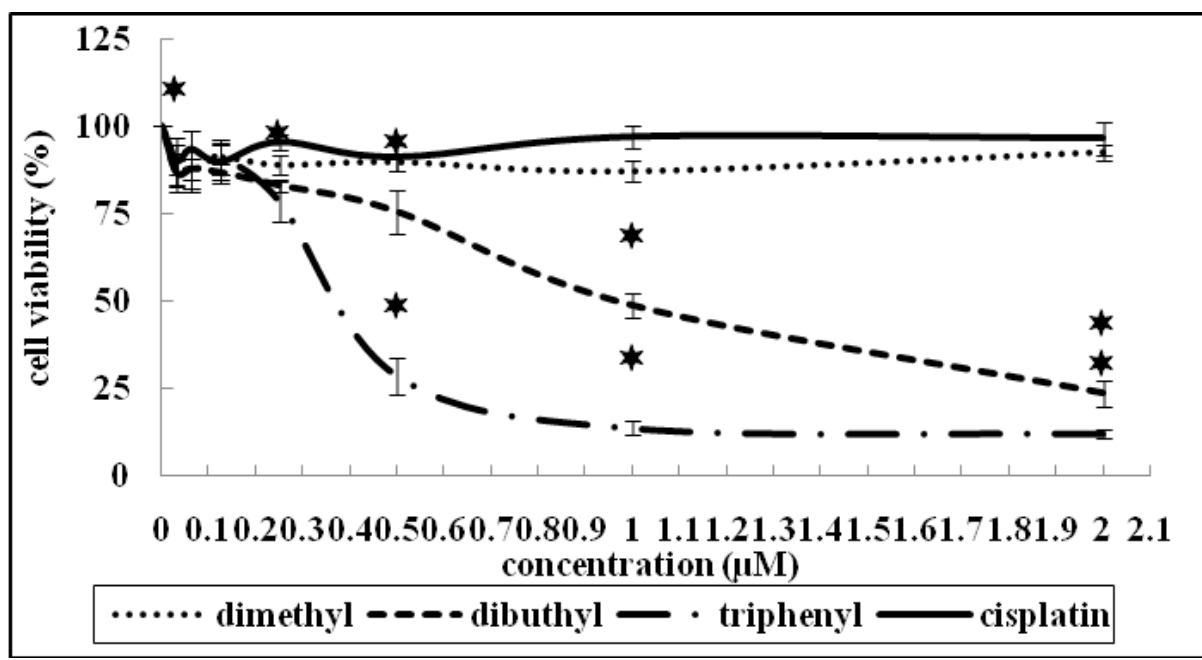

FIGURE 2. Cytotoxic effect of compound 1, 2, 3 and cisplatin on K-562 after (a) $24 \mathrm{~h}$, (b) $48 \mathrm{~h}$ and (c) $72 \mathrm{~h}$ treatment. The results were presented as mean \pm S.E.M. of two triplicates in three separate experiments; ${ }^{*} \mathrm{p}<0.05$ vs. control

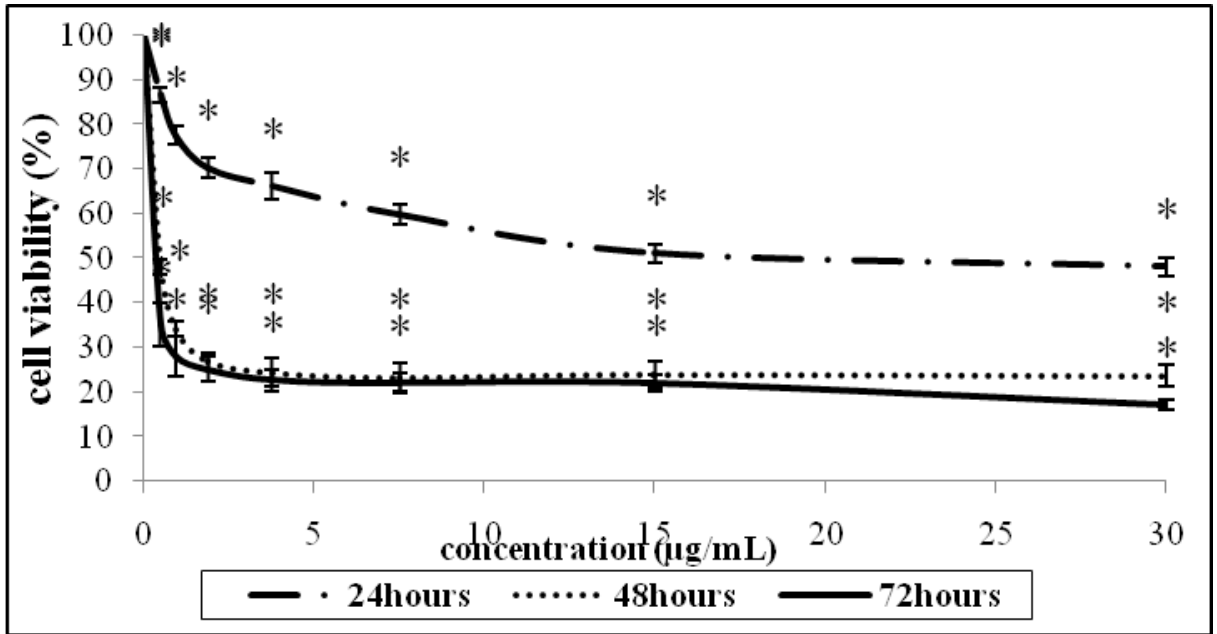

FIGURE 3. Cytotoxic effect of doxorubicin on K-562 after 24, 48, and $72 \mathrm{~h}$. The results were presented as mean \pm S.E.M. of two triplicates in three separate experiments; ${ }^{*} p<0.05$ vs. control

Morphological observation was conducted on $\mathrm{K}-562$ cells to observe the changes of the cell morphology exposed to $\mathrm{IC}_{50}$ value obtained from MTT assay for each compound. The morphological changes could be observed as early as $24 \mathrm{~h}$ of treatment (Figure 4) and the most prominent changes can be seen at 48 and $72 \mathrm{~h}$ post-treatment (Figures 5 and 6). The changes that were observed are the cell became oval and shrinkage (Figure 5 ) and elongated with blebbing of the cell membrane (Figure 6). There were also a lot of lysed and apoptotic cells observed after $72 \mathrm{~h}$ of treatment as seen in Figure 6. 

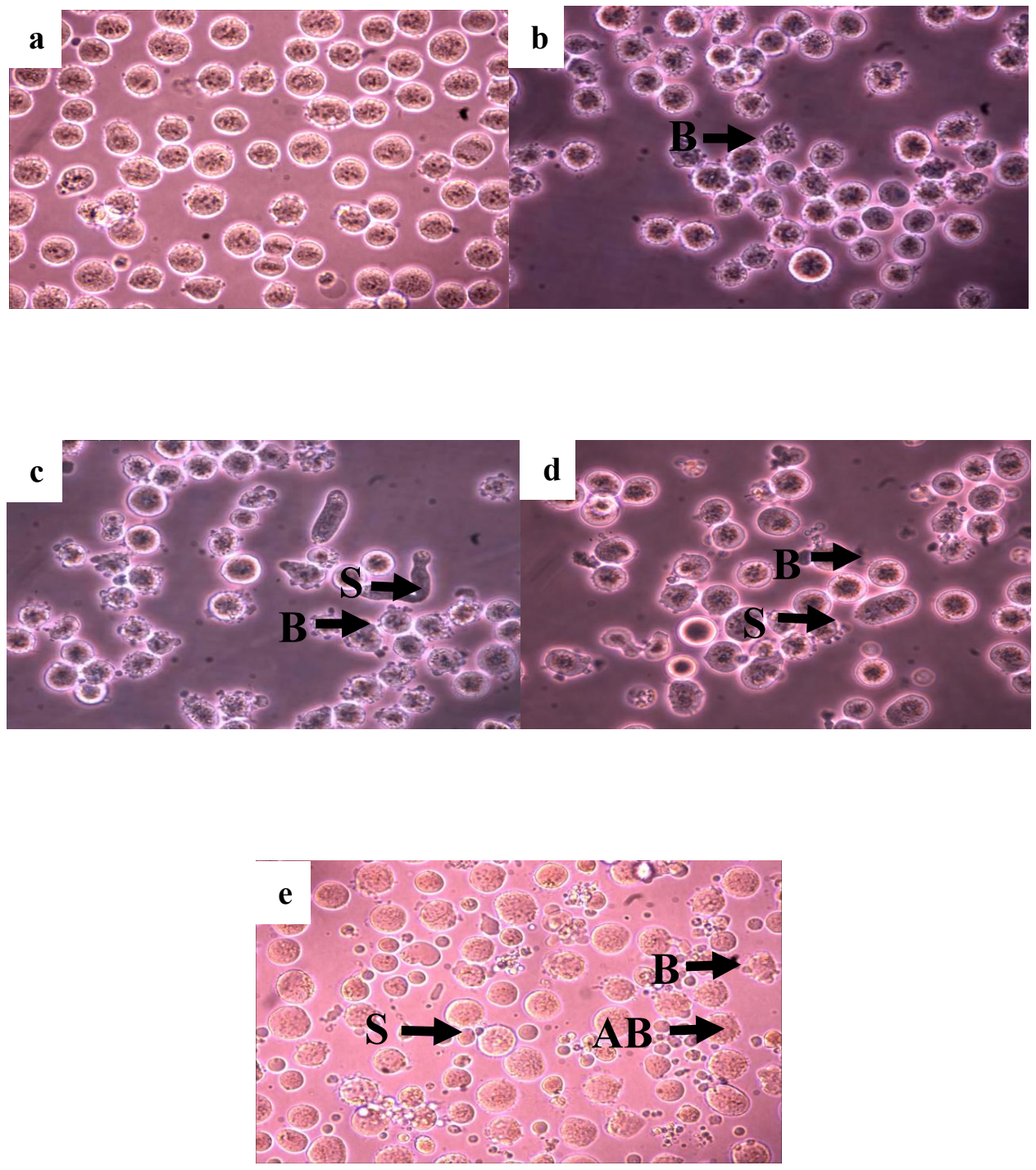

FIGURE 4. Morphology of K-562 cells after $24 \mathrm{~h}$ of treatment for observed under inverted microscope (magnification of $400 \times$ ). a) The control cells, b) cells treated with compound 1, c) cells treated with compound 2, d) cells treated with compound 3, and e) cells treated with doxorubicin. Apoptotic bodies (AB), cells shrinkage (S) and membrane blebbing (B) were observed

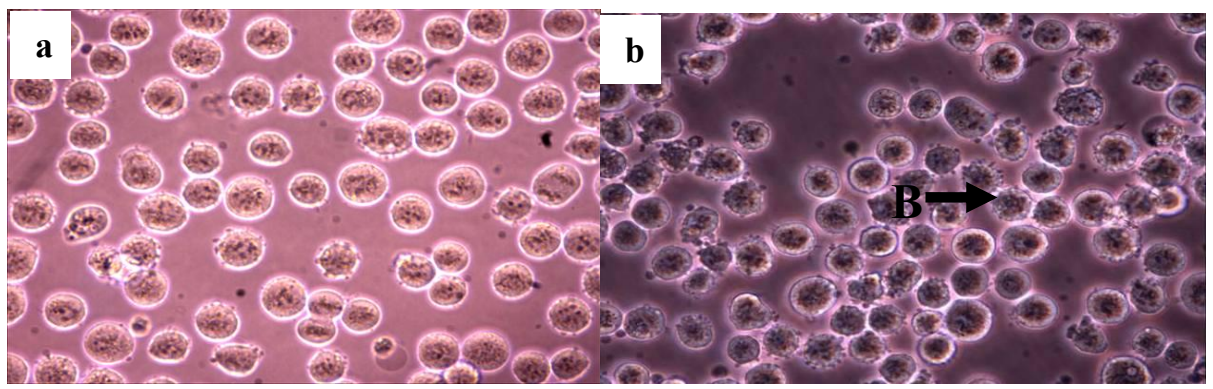

FigURE 5. 

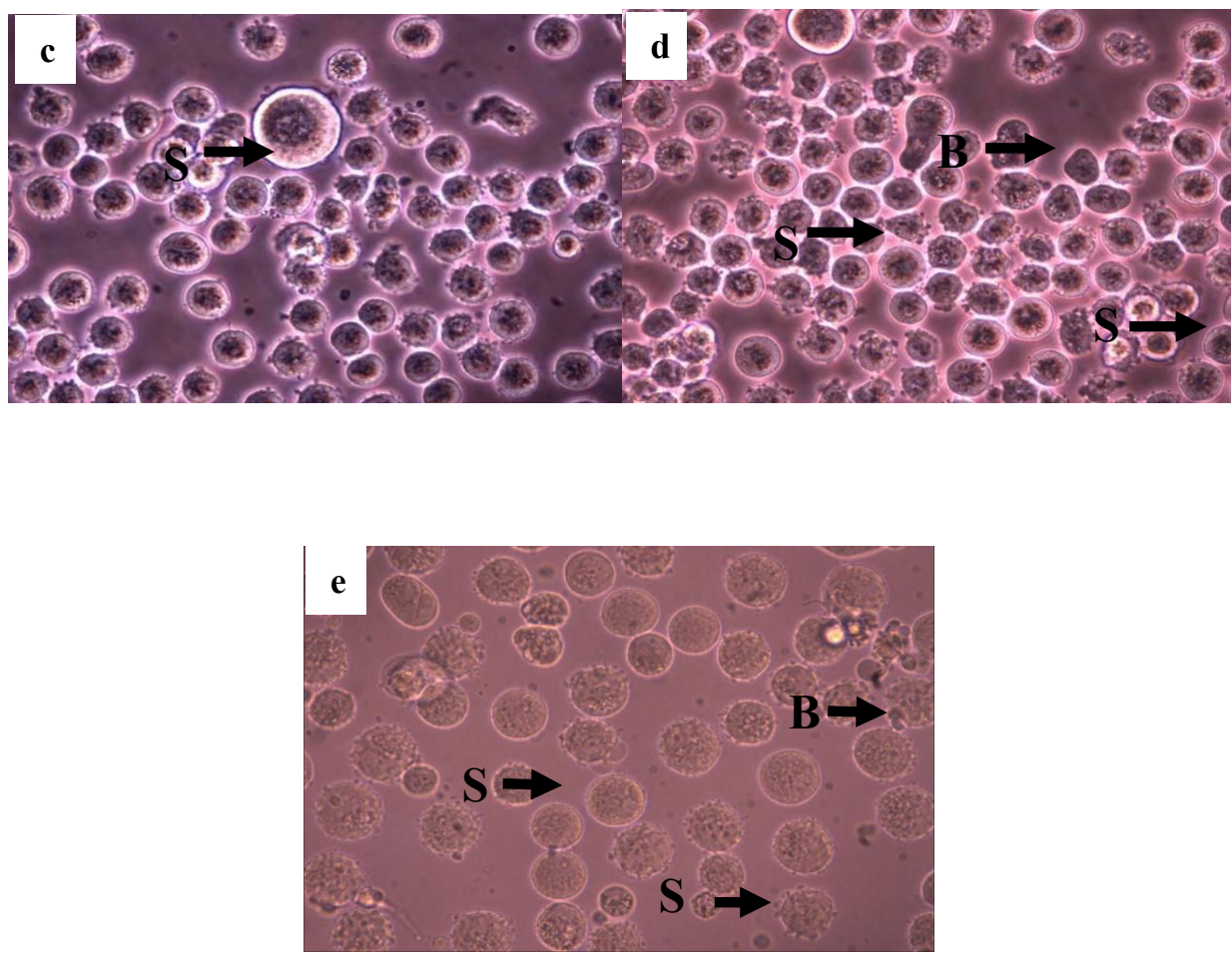

FIGURE 5. Morphology of K-562 cells after treatment for $48 \mathrm{~h}$ observed under inverted microscope (magnification of 400×). a) The control cells, b) cells treated with compound 1, c) cells treated with compound 2 , d) cells treated with compound 3 and e) cells treated with doxorubicin. Figure (b) shows membrane blebbing (B). For figure (c), (d) and (e), most of the cells changed their shape, became oval and shrinked (S)
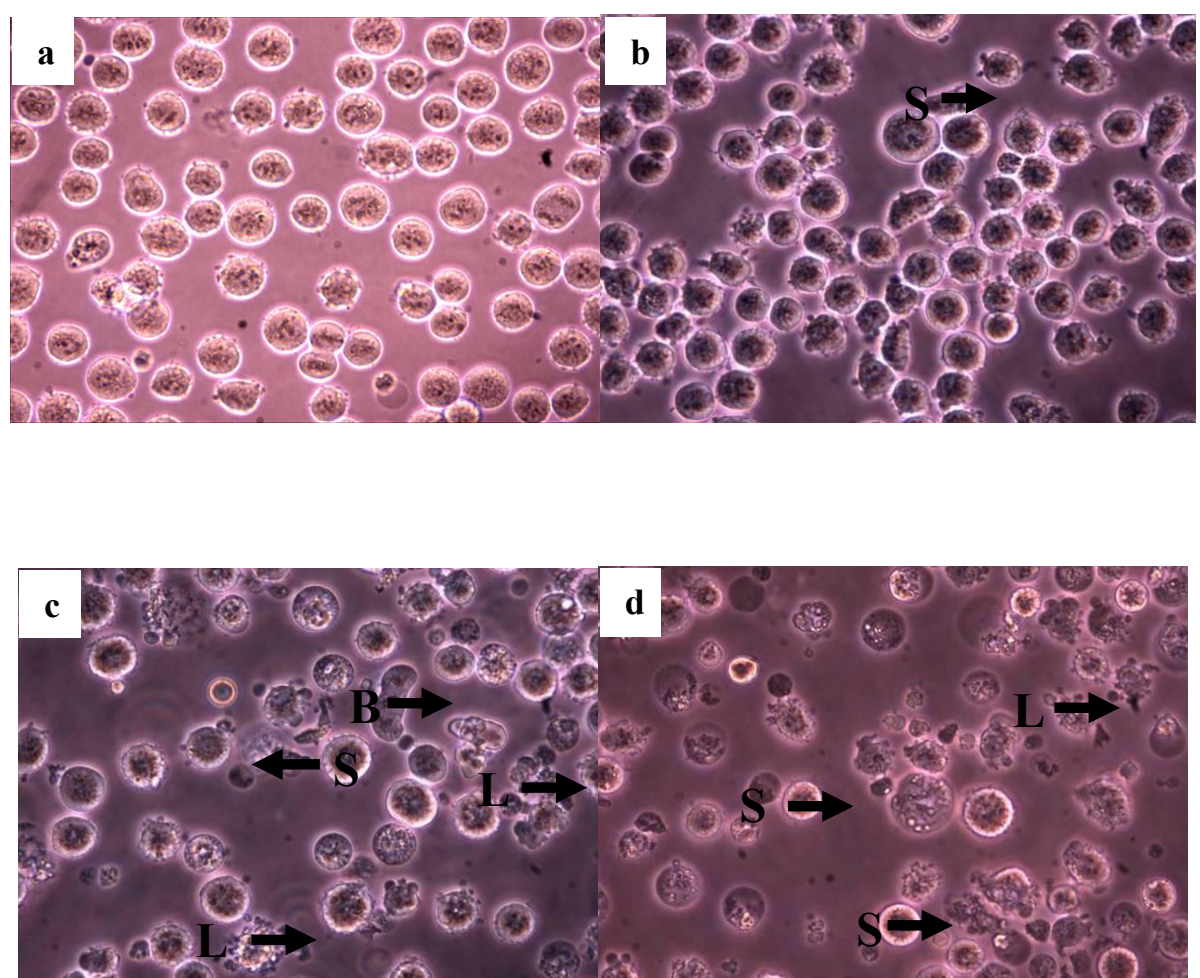


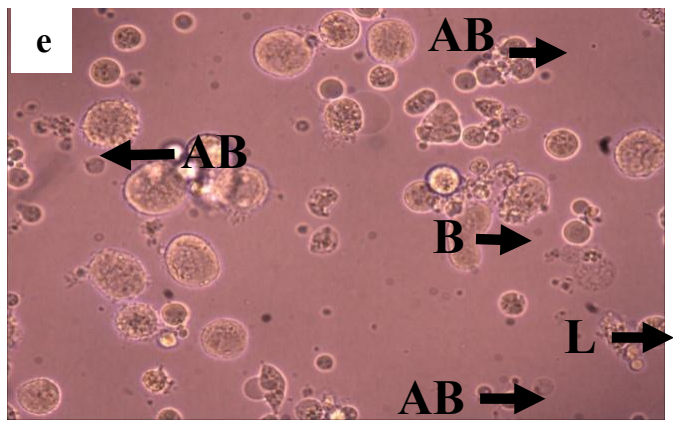

FIGURE 6. Morphology of K-562 cells after treatment for $72 \mathrm{~h}$ observed under inverted microscope (magnification of $400 \times$ ). a) The control cells, b) cells treated with compound $1, \mathrm{c})$ cells treated with compound 2 , d) cells treated with compound 3 and e) cells treated with doxorubicin. Figure (b) showed membrane blebbing (B). Figure (c), (d) and (e) most of the cells lysed (L) and presence of apoptotic bodies (AB)

All three tested compounds showed the potential to reduce the viability of K-562 cells. Compounds 2 and 3 had potent toxic effect towards the target K-562 cells. Between the three tested compounds, compound 3 which is triphenyltin(IV)methylisoprophyldithiocarbamate was the most toxic compound based on the lowest $\mathrm{IC}_{50}$ value $0.25 \mu \mathrm{M}(0.1245 \mu \mathrm{g} / \mathrm{mL})$ for $72 \mathrm{~h}$ period of treatment. The $\mathrm{IC}_{50}$ value for triphenyltin(IV) methylisoprophyldithiocarbamate toward leukemic $\mathrm{K}-562$ cell was within the range of $0.25 \mu \mathrm{M}-0.4 \mu \mathrm{M}$ even at different time of exposure. Previous study found that the triphenyltin complex compound tested on mouse tumour cells with $\mathrm{IC}_{50}$ between $0.16-0.18 \mu \mathrm{M}$ could reduce $96 \%$ of tumor cells viability in 11 days (Alama et al. 2009). These findings support the results that showed triphenyltin(IV)methylisoprophyldithiocarbamate compound is an active cytotoxic agent following the low $\mathrm{IC}_{50}$ value obtained. In this study, the $\mathrm{IC}_{50}$ values obtained showed that the K-562 cells had a good response which showed sensitivity towards the treatment with triphenyltin(IV)methylisoprophyldithiocarbamate compound. Compounds which has $\mathrm{IC}_{50}$ value less than 10 $\mu \mathrm{g} / \mathrm{mL}$ is considered a potential agent in the treatment of cancer and chemotherapy where the compound with the $\mathrm{IC}_{50}$ value more than $10 \mu \mathrm{g} / \mathrm{mL}$ is considered as having a weak cytotoxic activity (Shier 1991).

Based on the compounds used, the characteristics or nature of functional group which covalently bound to the tin(IV) atom plays an important role in influencing the cytotoxic activity of a compound (Hadjikakou \& Hadjiliadis 2009). Dimethyltin(IV) compound has hydrocarbon group which consist of two methyl and dibuthyltin(IV) compound has hydrocarbon group consist of two buthyl that attached to the tin(IV) atom. The hydrocarbon group which is phenyl attached to the
tin(IV) atom of triphenyltin(IV). Data obtained showed that compound 3 in this study was more toxic compared to compound 1 and 2 . This is due to the presence of more functional groups that are bound to the tin(IV) atom of compound 3 compared to 2 and 1 . These results are supported by the previous study using six dibuthyltin(IV) compounds and one triphenyltin(IV) compound and demonstrated that the triphenyltin(IV) compound was more toxic than dibuthyltin(IV) compound (Pellerito et al. 2006). In the study, all seven compounds were tested for their antitumor activity towards seven type of human cancer cells such as MEL A489 (renal cancer cell), EVSA-T (breast cancer cell), H226 (lung cancer cell). The median inhibition dosage $\left(\mathrm{ID}_{50}\right.$ ) obtained for six dibuthyltin(IV) compounds were between 25 and $478 \mu \mathrm{g} / \mathrm{mL}$, while the $\mathrm{ID}_{50}$ value that obtained for triphenyltin(IV) compound was between 6 and $30 \mu \mathrm{g} / \mathrm{mL}$.

The result of this study also showed that the toxic effect induced by compound 2 was higher than compound 1. Compound 2 has two buthyl groups, each of the group consists of four carbon atom that binds to the tin atom, while compound 1 has two methyl groups, each group consists of one carbon atom that binds to the tin atom. This result is supported by previous studies that showed increment of the length of linear carbon chain that binds to the tin atom will increase the toxicity of the organotin compounds (Argese et al. 1998).

Besides that, it can be concluded that the cytotoxic effects of all compounds were dependent on the concentration used in the treatment and the exposure time. This was further investigated by previous study that showed triphenyltin effects on growth and viability of the K-562 leukemia cells (Chikahisa et al. 1998). The study showed that the compound inhibits the growth of leukemia cells K-562 depending on the dose and 
duration of exposure to specific concentration for $72 \mathrm{~h}$. Comparative effects of triphenyltin compounds with other compounds like diphenyltin and monophenyltin were also performed. The results of the comparison showed that triphenyltin concentration inhibit $50 \%$ of K-562 cell growth in which the value was lower than diphenyltin and monophenyltin.

In this study, doxorubicin was used as positive control towards leukemic cell K-562. There was significant decrease in viability of K-562 with increasing concentration of doxorubicin compared to negative control. The toxicity effect of doxorubicin was increased with the increase of treatment duration. Doxorubicin is an antibiotic type of chemotherapeutic drugs, and it kills cancer via due to topoisomerase II inhibition and free radical generation that could lead to DNA damage and cell death (Rivankar 2014).

Cisplatin was used in this study for comparison with the research compound because cisplatin has chemical structure which almost similar to organotin compounds. Although cisplatin was not one of the anti-leukemic drugs and it has proven effective against solid malignant tumors such as lung, ovarian, and testis (Hirose et al. 2007). However, the experimental results showed that even its structure is almost similar with the organotin compound, it does not induce potents toxic effects as the tested compounds. Cisplatin did not produce potent toxic effect toward $\mathrm{K}-562$, as there is no $\mathrm{IC}_{50}$ value detected.

Morphological changes of K-562 cells which were treated with $\mathrm{IC}_{50}$ values of organotin(IV) compounds and doxorubicin in the treatments of 24,48 , and $72 \mathrm{~h}$ were observed using inverted microscope. Observation of K-562 morphology which were treated with compounds 2, 3 and doxorubicin showed that the cell begins to change in $24 \mathrm{~h}$ time of treatment. The changes that were observed include shrinkage of the cell and membrane blebbing which matched with the feature of apoptosis. Meanwhile, prominent changes such as apoptosis bodies were observed in the treatment of 48, and $72 \mathrm{~h}$, and these changes showed that the cells were undergoing apoptosis. In addition, the cells also went through necrosis that can be observed by the formation of cell swelling and cell lysis. This morphological changes of K-562 were similar to the morphological changes that shown in the previous study (Hamid et al. 2010). Membrane blebbing, cell shrinkage and formation of apoptotic bodies are signs of apoptosis (Kerr et al. 1972). Besides that, cell lysis and swelling were the major features of necrosis (Kroemer et al. 2009). These imply that compounds 2 and 3 were able to induce apoptosis and necrosis of K-562 cells. However, compound 1 showed no significant effect on the cell's morphology for the three different time points because the compound was not toxic to K-562 cell, based on MTT assay.

\section{CONCLUSION}

From this study, we found that the newly synthesized dimethyltin(IV)-, dibuthyltin(IV)- and triphenyltin(IV) methylisoprophyldithiocarbamatecompounds demonstrated to have cytotoxic characteristic because its ability to inihibit K-562 cells growth at low dose with triphenyltin(IV) methylisoprophyldithiocarbamatecompounds is the most toxic towards the cells.

\section{ACKNOWLEDGEMENTS}

This study was supported by UKM-NN-06FRGS0091-2010 grant. The authors would like to gratefully acknowledge the staffs of the Programme of Biomedical Science, Faculty of Health Sciences, Universiti Kebangsaan Malaysia for the help given throughout the research and the faculty itself for providing the facilities to conduct this research.

\section{REFERENCES}

Alama, A., Tasso, B., Novelli, F. \& Sparatore, F. 2009. Organometallic compounds in oncology: Implications of novel organotins as antitumor agents. Drug Discovery Today 14(9-10): 500-508.

Amir, M.K., Khan, S., Shah, A. \& Butler, I.S. 2014. Anticancer activity of organotin (IV) carboxylates. Inorganica Chimica Acta 423: 14-25.

Argese, E., Bettiol, C., Ghirardini, A.V., Fasolo, M., Giurin, G. \& Ghetti, P.F. 1998. Comparison of in vitro submitochondrial particle and Microtox ${ }^{\circledR}$ assays for determining the toxicity of organotin compounds. Environmental Toxicology and Chemistry: An International Journal 17(6): 1005-1012.

Awang, N., Zakri, N.H. \& Zain, N.M. 2016. Antimicrobial activity of organotin (IV) alkylisopropildithiocarbamate compounds. Journal of Chemical Pharmceutical Research 8: 862-866.

Awang, N., Jumat, H., Ishak, S.A. \& Kamaludin, N.F. 2014. Evaluation of the ex vivo antimalarial activity of organotin (IV) ethylphenyldithiocarbamate on erythrocytes infected with Plasmodium berghei NK 65. Pakistan Journal of Biological Sciences 17(6): 836-842.

Awang, N.F.K.N., Kamaludin, N. \& Ghazali, A.R. 2011. Cytotoxic effect of organotin (IV) benzylisopropyldithiocarbamate compounds on Chang liver cell and hepatocarcinoma HepG2 cell. Pakistan Journal of Biological Sciences 14(15): 768-774.

Baul, T.S.B., Paul, A., Pellerito, L., Scopelliti, M., Singh, P., Verma, P. \& de Vos, D. 2010. Triphenyltin (Iv) 2-[(E)2-(aryl)-1-diazenyl] benzoates as anticancer drugs: Synthesis, structural characterization, in vitro cytotoxicity and study of its influence towards the mechanistic role of some key enzymes. Investigational New Drugs 28(5): 587599.

Buac, D., Schmitt, S., Ventro, G., Rani Kona, F. \& Ping Dou, Q. 2012. Dithiocarbamate-based coordination compounds as potent proteasome inhibitors in human cancer cells. Mini Reviews in Medicinal Chemistry 12(12): 1193-1201. 
Chikahisa, L., Oyama, Y., Iguchi, Y., Okazaki, E., Miyoshi, N., Satoh, M. \& Yamada, Y. 1998. Effects of triphenyltin on growth and viability of K562 leukemia cells. Environmental Toxicology and Pharmacology 6(4): 209-215.

Gleeson, B., Claffey, J., Ertler, D., Hogan, M., Müller-Bunz, H., Paradisi, F., Wallis, D. \& Tacke, M. 2008. Novel organotin antibacterial and anticancer drugs. Polyhedron 27(18): 3619-3624.

Gómez-Ruiz, S., Kaluđerović, G.N., Prashar, S., Hey-Hawkins, E., Erić, A., Žižak, Ž. \& Juranić, Z.D. 2008. Study of the cytotoxic activity of di and triphenyltin (IV) carboxylate complexes. Journal of Inorganic Biochemistry 102(12): 2087-2096.

Hadjikakou, S.K. \& Hadjiliadis, N. 2009. Antiproliferative and anti-tumor activity of organotin compounds. Coordination Chemistry Reviews 253(1-2): 235-249.

Hamid, A., Ali, A.M., Alitheen, N.B., Rajab, N., Sirat, H. \& Awang, N. 2010. Apoptotic effect of zerumbone on mouse myelomonocytic leukemia cell line, Wehi-3b. In Proceedings International Seminar on Food and Agricultural Sciences.

Hirose, A., Sato, E., Fujii, H., Sun, B., Nishioka, H. \& Aruoma, O.I. 2007. The influence of active hexose correlated compound (AHCC) on cisplatin-evoked chemotherapeutic and side effects in tumor-bearing mice. Toxicology and Applied Pharmacology 222(2): 152-158.

Hogarth, G. 2012. Metal-dithiocarbamate complexes: Chemistry and biological activity. Mini Reviews in Medicinal Chemistry 12(12): 1202-1215.

Hunakova, L., Macejova, D., Toporova, L. \& Brtko, J. 2016. Anticancer effects of tributyltin chloride and triphenyltin chloride in human breast cancer cell lines MCF-7 and MDAMB-231. Tumor Biology 37(5): 6701-6708.

Kamaludin, N.F., Zakaria, S.A., Awang, N., Mohamad, R. \& Pim, N.U. 2017. Cytotoxicity assessment of organotin (IV)(2-metoxyethyl) methyldithiocarbamate compounds in human leukemia cell lines. Oriental Journal of Chemistry 33(4): 1756-1766.

Kerr, J.F., Wyllie, A.H. \& Currie, A.R. 1972. Apoptosis: A basic biological phenomenon with wide- ranging implications in tissue kinetics. British Journal of Cancer 26(4): 239-257.

Kroemer, G., Galluzzi, L., Vandenabeele, P., Abrams, J., Alnemri, E.S., Baehrecke, E., Blagosklonny, M., El-Deiry, W., Golstein, P. \& Green, D. 2009. Classification of cell death: Recommendations of the nomenclature committee on cell death 2009. Cell Death and Differentiation 16(1): 3-11.
Pellerito, C., Nagy, L., Pellerito, L. \& Szorcsik, A. 2006. Biological activity studies on organotin (IV) $n+$ complexes and parent compounds. Journal of Organometallic Chemistry 691(8): 1733-1747.

Rivankar, S. 2014. An overview of doxorubicin formulations in cancer therapy. Journal of Cancer Research and Therapeutics 10(4): 853-858.

Shier, W.T. 1991. Mammalian cell culture on $\$ 5$ a day: A laboratory manual of low cost methods. Los Banos, University of the Philippines 64(8): 9-16.

Tian, L., Shang, Z., Zheng, X., Sun, Y., Yu, Y., Qian, B. \& Liu, X. 2006. Synthesis, characterization and biological activity of diphenyltin (IV) complexes of N-(3, 5dibromosalicylidene)- $\alpha$-amino acid and their diphenyltin dichloride adducts. Applied Organometallic Chemistry 20(1): 74-80.

Varela-Ramirez, A., Costanzo, M., Carrasco, Y.P., Pannell, K.H. \& Aguilera, R.J. 2011. Cytotoxic effects of two organotin compounds and their mode of inflicting cell death on four mammalian cancer cells. Cell Biology and Toxicology 27(3): 159-168.

Asmah Hamid*, Mohd Azam Azmi, Nor Fadilah Rajab \& Nurul Farhana Jufri

Programme of Biomedical Science

Faculty of Health Sciences

Universiti Kebangsaan Malaysia

Jalan Raja Muda Abdul Aziz

50300 Kuala Lumpur, Federal Territory

Malaysia

Normah Awang

Programme of Enviromental Health \& Industrial Safety

Faculty of Health Sciences

Universiti Kebangsaan Malaysia

Jalan Raja Muda Abdul Aziz

50300 Kuala Lumpur, Federal Territory

Malaysia

*Corresponding author; email: asmah0901@ukm.edu.my

Received: 19 July 2019

Accepted: 3 February 2020 